$\square$ 증 례

\author{
종격동에 발생한 악성 섬유성 조직구종 1 예 \\ 연세대학교 의과대학 내과학교실 \\ 오제덕・김형중・안철민・김성규・이원영
}

병리학교실

정 현 주・이 광 길

훙부외과학교실

이 두 연

$=$ Abstract $=$

\title{
A Case Report of Primary Mediastinal Malignant Fibrous Histiocytoma
}

Jea Duk Oh, M.D., Hyung Jung Kim, M.D., Chul Min Ahn, M.D.

Sung Kyu Kim, M.D. and Won Young Lee, M.D.

Department of Internal Medicine, College of Medicine, Yonsei University, Seoul, Korea

\author{
Hyeon Joo Jeong, M.D., Kwang Kyl Lee, M.D. \\ Department of Pathology \\ Doo Yun Lee, M.D. \\ Department of Chest surgery
}

The malignant fibrous histiocytoma was first described in 1964 by O'Brien and Stout. Since then, malignant fibrous histiocytoma was recognized as the most common soft tissue sarcoma in adult. It involves the extremities, retroperitoneum, and trunk. The prognosis is poor and the depth and histologic grade affect survival. The primary mediastinal malignant fibrous histiocytoma is a rare disease of all malignant fibrous histiocytoma.

We have experienced a case of primary mediastinal malignant fibrous histiocytoma, which was confirmed by biopsy with thoracotomy. Histologically, the tumor in our case was pleomorphic type and the patient received post-operative radiation therapy. We presented a case of primary mediastinal malignant fibrous histiocytoma with review of literatures.

\section{서 론}

악성 섬유성 조직구종(malignant fibrous histiocytoma)은 1964년 O'Brien과 Stout등이 처음 기술 한 이래 연조직 종양 (soft tissue sarcoma) 중 가장 흔한
질환으로 과거에는 다형태성 지방육종(pleomorphic liposarcoma), 횡분 근육종(rhabdomyosarcoma) 혹 은 섬유육종(fibromyosarcoma)으로 분류되어 왔 다 ${ }^{4,9,19)}$.

이 질환의 호발 부위는 사지 및 후복막이며 홍부에 생 기는 예는 흔하지 않은 것으로 알려져 있으며 특히 폐에 
는 전이성으로 오는 경우는 흔한 반면 원발성으로 오는 경우는 흔치 않다. 1979년 Bedrossian등이 원발성 폐질 환을, 1982년 Mills등이 원발성 종격동 질환을 처음 보 고한 이래 세계적으로 약 20 예 정도의 훙부질환이 보고 되었다 ${ }^{15,20,23)}$.

최근 저자등은 종격동 종괴를 가진 환자에서 경피적 생검술을 시행하여 악성 섬유성 조직구종 의심하에 수술 하여 확진한 1 예를 경험하였기에 문헌 고찰과 함께 보고 하는 바이다.

\section{증 례}

환 자 : 안 $\bigcirc$ 호, 60 세, 남자.

주 소 : 기침, 가래 및 우상부 훙통.

현병력 : 환자는 9개월 전부터 기침, 가래가 있었으 나, 특별한 진단없이 약국에서 대증 용법으로 지내던중 2개월전부터 상기증상이 심해지며, 우상부 흥통 및 호흡 곤란이 동반되어 본원에 내원하였다. 환자는 상기 증상 발현후 $9 \mathrm{~kg}$ 의 체중 감소가 있다고 하였다.

과거력 : 흡연자.로서 폐결핵, 고혈압 및 당노병의 기 왕력은 없음.
가족력 : 특이사항 없음.

이학적 소견 : 입원당시 혈압은 $120 / 80 \mathrm{mmHg}$, 맥박 수 80 회 $/ \mathrm{min}$, 호흡수 20 회 $/ \mathrm{min}$, 체온은 $37.5^{\circ} \mathrm{C}$ 였다. 환자는 만성병색이었으며 경부 임파절은 촉지되지 않았 다. 향부 청진 소견상 혼탁음이 들렸으나, 천명음이나 수포음은 들리지 않았다. 그외 심장, 복부와 사지 진찰 시 이상 소견은 없었다.

검사 소견 : 백혈구수 $9,400 / \mathrm{mm}^{3}$ (다핵구 $69 \%$, 임파 구 $17 \%$, 단핵구 $14 \%)$, 혈색소치 $9.5 \mathrm{mg} / \mathrm{dl}$, 혈소판수 $645,000 / \mathrm{mm}^{3}$ 이었으며 혈청 iron $20 \mathrm{ug} / \mathrm{dl}$, TIBC 237 $\mathrm{ug} / \mathrm{dl}$ 이었고 소변검사, 대변검사 및 혈청 전해질검사는 정상이었다. 혈청 생화학 검사상 총단백 $7.3 \mathrm{~g} / \mathrm{dl}$, 알부 민 $2.8 \mathrm{~g} / \mathrm{dl}, \quad$ SGOT 102 unit, SGPT 94 unit이었으며 그외는 정상이었다.

홍부 X-선 촬영상 우측 상부에 종격동 종괴의 소견을 보였다(Fig. 1). 훙부 전산화 단층 촬영상 우측 상 종격 동에 비교적 경계가 뚜렷한 $15 \times 10 \times 10 \mathrm{~cm}$ 크기의 내부 에 여러군데 저음영 소견을 보이며 주위장기를 압박하는 종괴가 보였다(Fig. 2).

객담 항상균 검사 및 세포학적 검사에 이상 소견 없었 으며, 폐기능 검사 소견은 $\mathrm{FEVl}: 1.98 \mathrm{~L} / \mathrm{sec}$ (예측치의
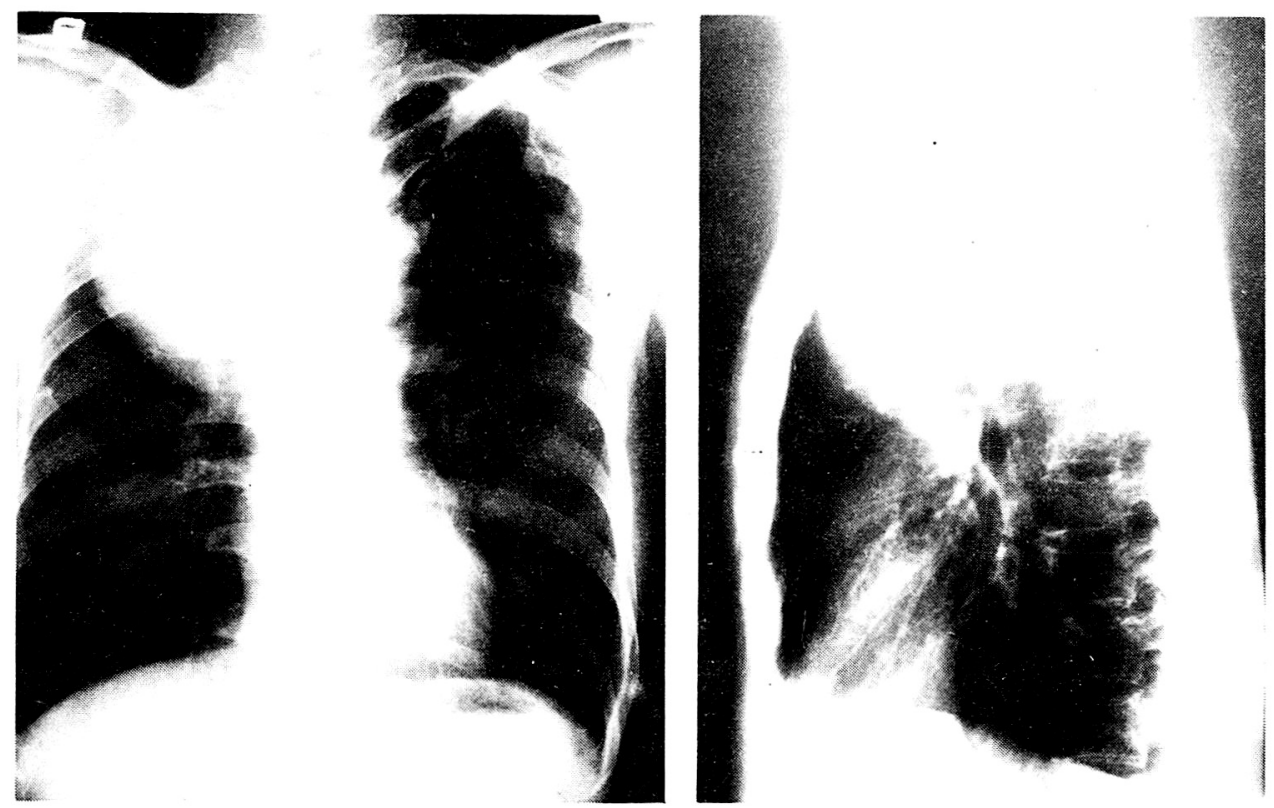

Fig. 1. Chet PA and lateral view: well defined huge mass of mediastinal origin. 
$61 \%$ ), $\mathrm{FVC}: 2.55 \mathrm{~L} / \mathrm{sec}$ (예측치의 $61 \%$ ) 였으며, 기관 지경검사상 외부병변에 의한 우측 상엽기관지의 부분폐 쇄소견을 보였다.

조직학적 진단을 위해 초음파 유도하에 경피적 생검술 을 시행한 결과 육종 특히 악성 섬유성 조직구종이나 지 방 육종의 소견을 보였다. 전이 여부를 확인하기 위해 골 수 검사, 전신골주사 검사 및 복부 초음파 검사를 시행 하였으나 정상 소견을 보였다. 환자는 종격동에 생긴 육 종 진단하에 수술하였다.

수술 소견 : 수술 소견상 $20 \times 15 \times 10 \mathrm{~cm}$ 크기의 종괴 가 종격동, 우측 늑막 및 폐의 상엽, 상대 정맥 및 훙벽

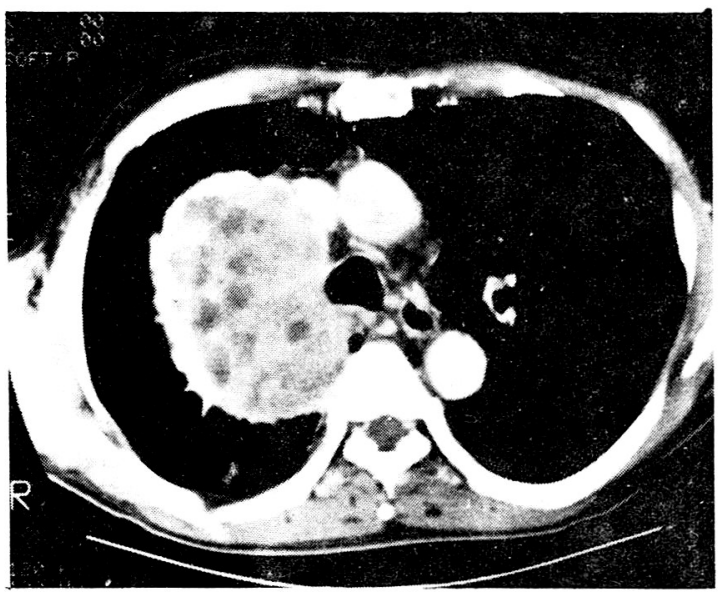

Fig. 2. CT Scan of chest: $15 \times 10 \times 10 \mathrm{~cm}$ sized mediastinal mass with multiple low densities.
에 유착되어 있었으며 전기관지부, 기관지방부, 하훙봉 부에 임파선 비대 소견이 있었다. 수술은 우측 전폐 제 거술과 함께 임파선을 포함하여 종양 침윤 조직의 제거 술을 시행하였다.

조직학적 소견 : 육안적 소견상 종괴의 외견은 불규칙 하였고, 절단시 다엽상으로 연분홍색 또는 회백색이었 으며, 다발성의 출혈성 괴사 소견이 관찰되었다(Fig. 3). 현미경 소견에서 종괴는 심한 출혈성 괴사소견을 보 이며 다형태성 세포들이 특별한 유형없이 배열되어 있었 다. 종양세포의 핵은 수포성으로 핵인이 뚜렷하고, 세포 질은 풍부하며 호산성으로 방추형 또는 다각형이었다. 부분적으로 종양세포들이 융합되어 다핵세포를 형성하

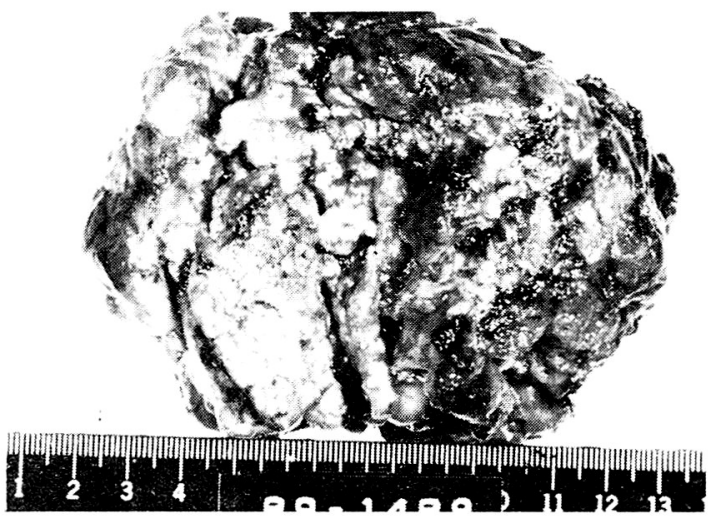

Fig. 3. Gross appearance: $20 \times 15 \times 10 \mathrm{~cm}$ sized, irregular and multinodular mass which infiltrate into surrounding lung parenchyme and pleura.

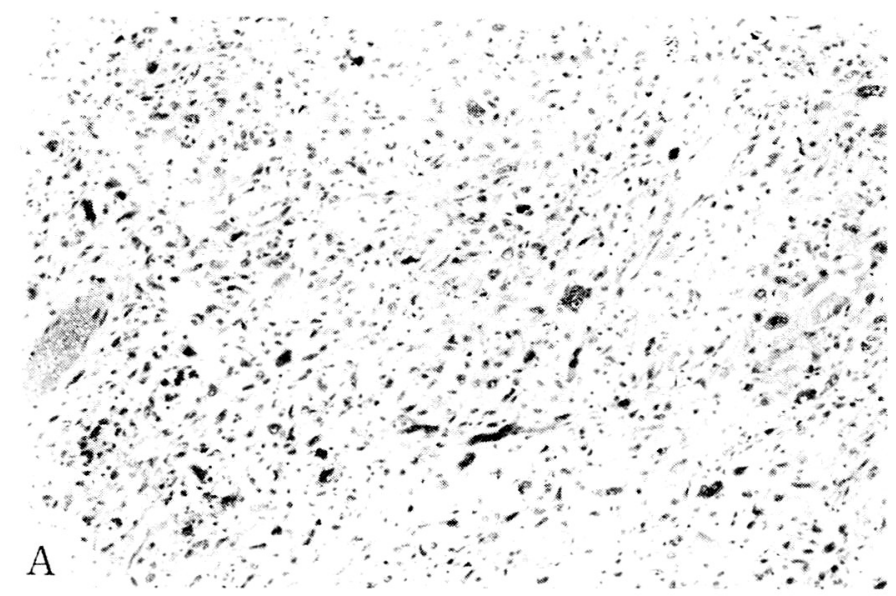

Fig. 4-A. Microscopic appearance: The pleomorphic tumor cells are in plate-like arrangement, and mixed with abundant capillaries and inflammatory cells. (H-E. x 100) 


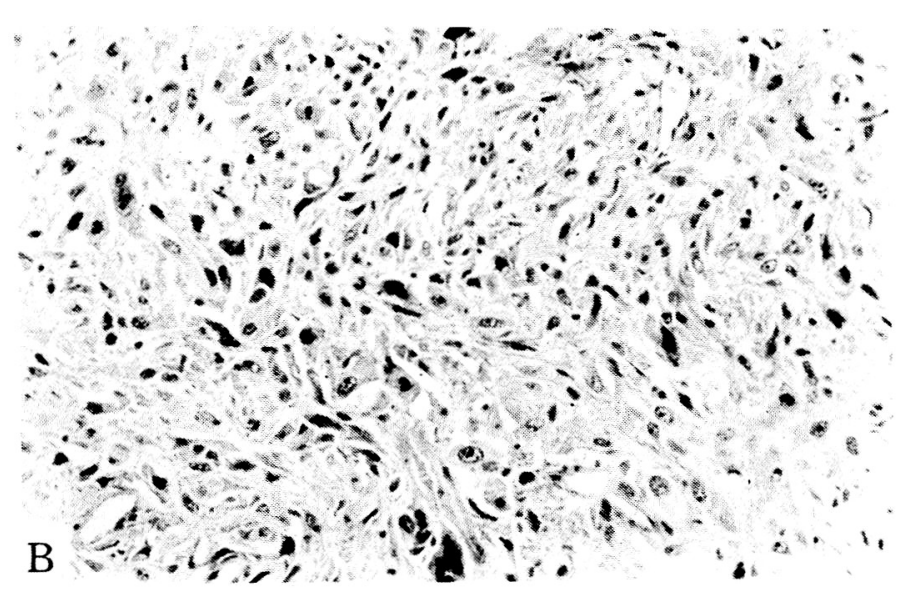

Fig. 4-B. The tumor cells are spindle-shaped, and nuclei of which are vacuolated and hyperchromic. Many mitotic figures are present. (H-E, x400)

였으며 핵분열상이 자주 관찰되었다(Fig. 4-A,B).

종양내 혈관은 풍부하였으며, 종양세포는 늑막, 폐실 질 및 후 훙막내로 침윤하고 있었으나, 기관지 절개시 점 막의 종양 침윤은 관찰할 수 없었다. 전기관지부, 기관 지방부, 하홍봉부 및 폐문부 임파절에 종양의 전이 소견 은 관찰되지 않았다. 조직의 특성을 확인하고자, 면역조 직 화학적 검사를 시행한 결과, $\alpha$-1-antitrypsin에 양성 이었고, s-100과 cytokeratin에 음성이었다.

임상 경과 : 수술 1 개월후부터 $6000 \mathrm{rad}$ 의 방사선 치 료를 3 개월간 받은후 현재 5 개월째 외래에서 경과 관찰 중이다.

\section{고 찰}

1964년 O'Brien과 Stout등이 연조직 육종(sarcoma) 중에서 악성 섬유성 조직구종 (malignant fibrous histiocytoma, MFH)을 따로 분류한 이후3), 섬유육종 (fibrosarcoma), 지방육종(liposarcoma), 평활근육종 (leiomyosarcoma), 횡문근육종(rabdomyosarcoma) 등에 포함되어 있던 많은 연조직 종양이 악성 섬유성 조 직구종은 연조직 종양중 가장 많은 부분을 차지하는 것 으로 알려져 있다 ${ }^{10,11)}$.

악성 섬유성 조직구종의 조직학적 기원과 조직 형성 과정(histogenesis) 은 1963년 Ozzello등2)이 조직 배양 에 의해 조직구로부터 기인하며 조직구기 특별한 환경에
서 섬유아세포로 분화하는 것으로 보고한 이래 1975년 $\mathrm{Fu}$ 등은 ${ }^{8)} \mathrm{MFH}$ 의 전자 현미경적 소견상 조직구세포, 섬 유아 세포 및 미분화된 간엽세포(mesenchymal cell) 로 구성되어 있는데 이 미분화된 간엽세포를 조직구 세포 및 섬유아 세포의 종양 전구 세포로 판단하면서 $\mathrm{MFH}$ 의 조직학적 기원은 미분화된 간엽세포로 보고하였다.

그후 여러 학자에 의해 조직 배양, 전자 현미경적 소 견, 면역조직 화학적 검사 및 monoclonal antibody방 법에 의한 연구가 많이 진행되었으며, 1986년 James등 은 ${ }^{22)} \mathrm{MFH}$ 의 조직구에는 단핵구와 대식세포에 존재하 는 T-200, Ia, MsSl, MoS-39, MoR-17등에 대한 monoclonal antibody을 확인하였으며 방추형 세포에 도 이런 항원이 존재하는 것을 확인하였는데 이는 어떤 조건하에서 조직구가 방추형 세포로 형태학적 변형 (so-called facultative fibroblast)을 보인것으로 결국 $\mathrm{MFH}$ 의 조직학적인 기원은 단핵과 대식세포 발생설로 가장 널리 받아들여지고 있다 ${ }^{16,17)}$.

악성 섬유성 조직구종의 조직학적 소견은 조직구 세 포, 섬유아 세포의 상대적 비율 및 기질의 교원질화와 염 증 소견의 정도에 따라서 조직학적 소견이 다양하며 종 종 조직내에 다형태성 거대세포 및 염증세포들이 존재하 여 이들 세포 및 기질 비율에 따라 섬유성, 점액성, 거 대세포 및 염증성등의 조직학적 아향으로 분류하며 이들 중에 흔히 볼수 있는 섬유성 아형은 충실한 섬유성 기질 낵에 다형태성 방추세포가 storiform arrangement소 
견을 보이며 점액성 아형은 mucopolysaccharide로 구 성된 점액성 기질내에 방추형 세포가 드물게 분포된 소 견을 보이며 거대세포 및 염증세포 아형은 각각 기질내 에 다핵성 거대세포 및 호중성구, 형질세포, 임파구등 염증 세포가 많이 존재하며 이런 양상은 다른 형태의 종 양내에서도 부분적으로 관찰할 수 있다 ${ }^{27)}$.

이 질환의 호발 부위는 Enzinger ${ }^{9}$ 와 Kearney등 ${ }^{11}$ 의 보고에 의하면 하지 $49 \sim 51 \%$, 상지 $19 \sim 24 \%$ 후복막 $9 \sim 16 \%$ 및 체간 $16 \%$ 등이며, 홍부 질환은 전이성폐질환 은 흔한 것으로 알려져 있으나 원발성 폐질환은 세계적 으로 15예 정도 보고되어 있다. 그외에도 1980년 Hamada등 ${ }^{13)}$ 이 좌심방, 1982년 Mills등15)이종격동, 1982년 Yang등이 ${ }^{18)}$ 늑막, 1987년 Van등이 ${ }^{25)}$ 폐동맥에 발생한 $\mathrm{MFH}$ 을 보고하여 현재까지 홍부의 $\mathrm{MFH}$ 는 약 20예 정도 보고되어 있다 ${ }^{23)}$.

이 질환의 임상적 소견은 1978년 Enzinger 및 1980년 Kearney등의 보고에 따르면 중년이후 50 60세에 가장 흔하게 나타나며 남녀간의 성별에 따른 빈도에 차이는 없다. 본 질환은 주위 조직의 침투 및 다른 조직으로 전 이가 흔하며, 전이로는 폐로 전이가 $82 \%$, 주위 임파선 전이가 $32 \%$, 그외에 간, 골 및 뇌전이등이 있으며 전이 경로는 대부분 혈행성으로 알려져 있다. Kearney등은 증상발현 시기는 약 3 개월정도로서, 관찰시 대부분 종괴 를 촉지하였고, 이중 $20 \%$ 는 종괴부위에, $10 \%$ 는 주위조 직에 통증이 있었으며, 약 $55 \%$ 의 환자에서는 통증을 느 끼지 못했다. 이외 발열, 체중감소, 전신쇠약, 위장관장 애등이 나타나며, 발생부위에 따른 특이증상이 나타난 다고 ${ }^{911)}$ 보고하였으나, 이는 대부분이 사지와 체간의 경 우이며, 종격동을 포함한 홍부질환의 임상적 소견은 증 례가 많지 않아 보고가 없는 실정이다.

악성 섬유성 조직구종의 진단에는 조직학적 소견이 필 수적이며, 확진 및 감별진단에 상술한 전자현미경 및 면 역 조직 화학적소견이 도움이 되는 것으로 되어 있다. 수 술전 세침조직 검사하여, Comet cell을 확인함으로써 진단에 도움을 받을 수 있으나, 미분화 대세포 폐종양과 의 구별이 매우 어려운 것으로 되어있다 ${ }^{23)}$. 미분화 대세 포 폐종양은 크고 둥근 핵내에 인이 뚜렷하게 보이고, 중 등도의 과립성 세포질로 구성되는 반면 이 질환은 "comet" 모양의 방추형이며, 여러개의 핵을 가진 세포 질로 구성되어 있다. 또한 이 종양은 매우 다양한 형태 를 나타내므로, 작은 양의 조직만 가지고는 다른 다형태
성 육종 (pleomorphic sarcoma) 과 혼돈하는 경우가 많 기때문에, 세침조직검사 만으로는 진단에 무리가 있 어 ${ }^{21}$, open biopsy가 절대적으로 필요하다.

전자현미경하에서 악성 섬유성 조직구종은 섬유아 세 포와 조직구세포 (histiocytic cell) 가 혼합되어 있으며, 최근 개발된 면역조직 화학적 방법을 사용하여, $\alpha$-1-antitrypsin, lysozyme, CEA, keratin을 indirect immunoperoxidase stain하였을때, 이중 조직구 세포 가 $\alpha$-1-antitrypsin과 lysozyme에 양성반응을 나타내므 로 본 질환의 진단에 이를 이용한다 ${ }^{12,23)}$. 홍부 질환의 경 우는 이외에 전이여부를 확인하기 위해 전산화 단층촬 영, 종격경, 골주사 검사, 기관지경 검사등이 필요하 다 $5,6,24)$.

악성 섬유성 조직구종의 진행전도는 다른 육종과 마찬 가지로 AJC staging system을 많이 사용하는데 AJC staging system에서는 $\mathrm{T}$ (원발성 종양 크기 : $\mathrm{T} 1<5$ $\mathrm{cm}, \mathrm{T} 2>5 \mathrm{~cm}$ ), G(종양의 조직학 정도 : G1 low, G2 moderat, G3 high), $\mathrm{N}$ (주위 임파절으로의 전이여부 : NO no metastasis, N1 metastasis), $\mathrm{M}$ (다른 조직으 로의 전이 여부: MO no metastais, M1 metastasis) 에 따라 원발성병소를 stage I (A : GITINOMO, B : GIT2NOMO), stage I (A : G2T1NOMO, B : G2T2NOMO), stage III (A: G3T1NOMO, B : G3T2NOMO), stage IV (A : G1-3T1-2N-MO, B : G13T1-2NOM1)로 분류하여 이용하며 ${ }^{26)}$, 이외에 celluar pleomorphism, mitotic activity, nuclear chromatin의 pattern정도에 따라 Grade I IV로 구분한 Broder's system ${ }^{1)}$, Enneking classification등 ${ }^{14)}$ 이 많이 이용되 고 있다.

본 질환은 예후가 매우 불량하여, 종괴완전체거 수술 후 화학요법과 방사선 치료등의 병용치료에도 5 년 생존 율이 $40 \%$ 미만이다. 이는 본 질환이 주위조직으로의 침 투가 매우 심하고, 다른 부위로의 전이가 잘 일어나며, 종괴제거 후에도 재발율이 $50 \%$ 이상 될 정도로 재발율이 높기 때문으로 여겨진다 ${ }^{11}$.

악성 섬유성 조직구종의 치료는 외과적 절 제술이 가장 확실한 치료이며, 이외 항암요법이나 방사선 치료가 병 용되고 있으며, 특히 방사선 치료는 주로 수술후에 시행 되고 있으나, 이들 치료의 효과는 아직 확실하지 않다. 


\section{결 론}

저자들은 최근 종격동에서 발생하였을 것으로. 생각되 는 원발성 섬유성 악성 조직구종 1예를 경험하였기에 문 헌고찰과 함께 보고하는 바이다.

\section{REFERENCES}

1) Broaders AC, Hargrave R: Pathological features of the soft tissue fibrosarcoma with special referance to the grading of its malignancy. Surg Gynecol Obstet 69:267, 1939

2) Ozzello L, Stout AP, Murray MR: Cultural characteristics of malignant fibrous histiocytomas and fibrous xanthomas. Cancer 16:331-344, 1963

3) O'Brien JE. Stout AP: Malignant fibrous xanthoma. Cancer 17:1445-1458, 1964

4) Kempson RL, Kyriokos M: Fibroxanthoma sarcoma. Cancer 29:961-976, 1972

5) Levin DC, Wartson RC, Baltaxe HA: Arteriography in diagnosis and management of acquired peripheral soft tissue masses. Radiology 103:53-58, 1972

6) Martel W. Abell MR: Radiologic evaluation of soft tissue tumor. A retrospective study. Cancer 32:352 $-366,1973$

7) Wasserman TH, Stuart ID: Malignant fibrous histiocytoma with wide spread metastases. Autopsy study. Cancer 33:141-146, 1974

8) Fu Y, Gabbiani G, Kaye GI, Lattes R: Malignant soft tissue tumors of probable histiocytic origin. Cancer 35:176-198, 1975

9) Weiss SW, Enzinger FM: Malignant fibrous histiocytoma. An analysis of 200 cases. Cancer 41:2250 $-2266,1978$

10) Enjoji M, Hashimoto $H$, Iwasaki $H$ : Malignanant fibrous histiocytoma. A clinicopathologic study of 130 cases. Acta Pathol Jpn 30:727-741, 1980

11) Kearney MM, Soule EH: Malignant fibrous histiocytoma. A retrospective study of 167 cases. Cancer 45:167-178, 1980

12) Meister $P$, Nathrath $W$ : Immunoch mical markers of the histiocytic tumors. Hum Pathol 11300-301,
1980

13) Hamada N, Matsuzaki M, Kusukawa R: Malignant fibrous histiocytoma of the heart. Jpn Circ J 44:361 $-368,1980$

14) Enneking WF, Spanier SS, Goodman MA: The surgical staging of musculoskeletal sarcoma. J Bone Joint Surg (Am)62:1027-1030, 1980

15) Stephen AM, Robert HB: Malignant fibrous histiocytoma of the lung and mediastinum. J Thorac Cardiovasc Surg 84:367-372, 1982

16) Nathrath WBJ, Meister P: Lysozyme and alpha-1antichymotrypsin as immunohistochemical tumor markers. Acta Histochemical Suppl.Band XXV:69 $-72,1982$

17) Iwasaki $H$, Kikuchi $M$ : Benign and Malignant fibrous histiocytoma of the soft tissues. Cancer 50: 520-530, 1982

18) Hong YY, Leslie LW, Philip R: Malignant fibrous histiocytoma of the pleura. Acta Cytol 6683-687, 1983

19) Weiss SW, Enzinger FM: Soft tissue tumors. St Louis, CV Morsby:166-198, 1983

20) Franco B, Rodorf CL: Malignant fibrous histiocytoma of soft tissue. Cancer 56:356-367, 1985

21) Venn GE, Gellisten J: Malignant fibrous histiocytoma in thoracic surgical practice. J Thorac Cardiovasc Surg 91:234-237, 1986

22) James A, Alexandra D: Malignant fibrous histiocytoma. Am J Pathol 124:303-309, 1986

23) Jeng-Gwang H, John KK: Primary malignant fibrous histiocytoma of the lung. Acta Cytol 31:345 $-350,1987$

24) Chang AE, Matory YL: Magnetic resonance imaging versus computed tomography in the evaluation of soft tissue tumors of the extremities. Ann Surg 205:340-348, 1987

25) Van DH, Vaneerdeweg W, Schoofs E: Malignant fibrous histiocytoma of the pulmonary artery. Ann Surg 205:203-207, 1987

26) Stut HD, Mankin JH, Willette G: Limited surgery and external irradiation in soft tissue sarcoma. Proceedings of the international symposium on sarcoma treatment, October 8-10, 1987

27) Enzinger FM, Weiss SW: Soft Tissue Tumors. St Louis, CV Mosby, 1988 